\title{
INTERNET BANKING AND ITS IMPACT ON THE SERVICE QUALITY OF BANKS IN PUNJAB
}

${ }^{1}$ Rajni Bhalla, ${ }^{2}$ Dr. Inderpal Singh

${ }^{1}$ Research Scholar, Punjab Technical University, Jalandhar and Assistant Prof. in Commerce Panjab university Constituent College, Nihal Singh Wala, Moga, Punjab

rajnibhalla49@yahoo.in

${ }^{2}$ Associate Prof. in Management, KCL Institute of Management and Technology, Jalandhar, Punjab arora_inderpal@yahoo.co.in

\section{Abstract}

The changes in IT sector constantly influencing the performance of banking sector in the world. The emergence of internet banking has changed the way of banks of how to offer the products and services to the customers. In order to survive in the rapidly changing technological environment, the banks are required to adapt such changes and to maintain and improve the services which they are offering to their customers in order to attain the customer's satisfaction. Now the term quality does not only include the products but also the services. This paper deals with the internet banking operations and how it affects the service quality of the banks in Punjab. The research is much more of qualitative nature but to prove facts and figures quantitative approach is also used in the paper. The research is descriptive as well as explanatory. In order to arrive at the sample size, non probability method has been used. For the primary data collection a structured questionnaire is used to record the response of various respondents. Secondary data has been collected from annual reports, other published literature of the banks etc. In order to test the impact of internet banking on the service quality of banks seven service quality dimensions model is used. A model with seven dimensions service quality named reliability, assurance, responsiveness, empathy, tangibility, security and communication is used to complete the study. In these seven dimensions 37 variables are covered. For the data analysis the statistical package SPSS 20 is used. Descriptive statistics is used to analyse the data. The research proves that all the dimensions which are included in the study have a positive impact on the service quality of banks providing internet banking services to their customers in Punjab. The recommendations are also discussed with which the service quality and customers satisfaction can be improved.

Key Words: Internet Banking; Service quality; Customer Satisfaction; Seven Dimensional Service Quality Model.

Academic Discipline: Banking and Finance

\section{Council for Innovative Research}

Peer Review Research Publishing System

\section{Journal: Journal of Social Sciences Research}

\author{
Vol. 5, No. 2 \\ Jssreditor.cir@gmail.com
}

www.jssronline.com 


\section{INTRODUCTION:}

As we all know that customer is the king of the market because in the modern era customer is rational. A customer gas becomes very much particular towards the quality of the products and services which he is purchasing or intends to purchase from the market. The growing awareness of a customer has made him more quality conscious. Due to this each and every organization is required to provide product and services to the customers of high quality which must meet the set perceptions of customers regarding the product or service. As far as banking industry is concerned it comes under service sector and there is a lot of pressure on the banking industry to provide high quality services to its customers. This obligation is same for the public sector banks, private sector banks and foreign banks if they want to survive in the market. Quality is a dynamic state related with products, services, people, processes and the environment that meets or exceeds customer's expectations, needs or desires (De Jager H. J., Nieuwenhuis, 2005). The difference between the perceived customers' service and their expected service is defined as service quality (Parasuraman, Zeithaml and et al., 1988). In the banking industry this concept is gaining popularity because the competitive products and services are now offered by the different banks to their customers in order to retain their customers and also to enhance the customer base. The service quality of the banks is greatly affected due to the introduction of internet banking services also. The banks are now trying to increase their customer base by delivering banking services with the help of internet rather than by means of any other distribution media. But while delivering services with the help of internet the banking sector also faces several challenges as the banks have to design and provide their internet based services with the expectations of services by the customers. Today customers want to access the internet banking services as it is convenient and time consuming for the customer as well. But this is not the end and the expectations of the customers also involves secured transactional websites, easily navigable websites, protection of online personal information, diversification of internet based services, credibility, access to variety of services, communication by bank to the customer after using internet banking services like SMS alert service etc. ( Hassan, 2012).

\section{REVIEW OF LITERATURE}

The various empirical studies undertaken by various researchers are explained with the help of following table on the impact of internet banking on the service quality of the banks.

\begin{tabular}{|c|c|c|c|}
\hline & Study & $\begin{array}{l}\text { Country and Sample } \\
\text { Size }\end{array}$ & Outcomes of the Study \\
\hline 1. & $\begin{array}{l}\text { Dixit et al. } \\
(2010)\end{array}$ & $\begin{array}{l}\text { India, } \\
200 \text { Respondents }\end{array}$ & $\begin{array}{l}\text { Trust and Security are the main factors which influence the } \\
\text { customers to adopt internet banking. }\end{array}$ \\
\hline 2. & $\begin{array}{l}\text { Adapta } \\
(2008)\end{array}$ & $\begin{array}{l}\text { India and Australia, } \\
100 \text { Respondents }\end{array}$ & $\begin{array}{l}\text { Indian women are receptive to the adoption of internet } \\
\text { shopping due to lack of security and trust in internet shopping. }\end{array}$ \\
\hline 3. & $\begin{array}{l}\text { Safeena et al. } \\
(2010)\end{array}$ & $\begin{array}{l}\text { India, } \\
53 \text { Respondents }\end{array}$ & $\begin{array}{l}\text { Usefulness, ease of the use of system awareness regarding } \\
\text { online banking and risks related to this are the main factors } \\
\text { which persuade the customers to adopt internet banking. }\end{array}$ \\
\hline 4. & $\begin{array}{l}\text { Altıntaş et al. } \\
\text { (2007) }\end{array}$ & $\begin{array}{l}\text { Turkey, } \\
200 \text { Respondents }\end{array}$ & $\begin{array}{l}\text { Slow working, attitude towards the customers and improper } \\
\text { focus on the customer problem by the banks are the main } \\
\text { factors of the service quality problems. }\end{array}$ \\
\hline 5. & $\begin{array}{l}\text { Raman et al. } \\
\text { (2008) }\end{array}$ & $\begin{array}{l}\text { Malaysia } \\
150 \text { Respondents }\end{array}$ & $\begin{array}{l}\text { Internet users and non users have different perceptions } \\
\text { regarding service quality of electronic banking. }\end{array}$ \\
\hline 6. & $\begin{array}{l}\text { Rullis et al. } \\
\text { (2011) }\end{array}$ & $\begin{array}{l}\text { Lativa } \\
1273 \text { Respondents }\end{array}$ & $\begin{array}{l}\text { Internet banking users are satisfied with its reliability, usability } \\
\text { and quality. } \\
\text { Customers' positive attitude towards internet banking helps to } \\
\text { recommend internet banking to others which proves their } \\
\text { loyalty. }\end{array}$ \\
\hline 7. & $\begin{array}{l}\text { Vasagadekar, } \\
\text { P. } \\
(2012)\end{array}$ & $\begin{array}{l}\text { India } \\
15 \text { banks; } 60 \text { Bank } \\
\text { Customers \& } 15 \text { Bankers }\end{array}$ & $\begin{array}{l}\text { Perceived usefulness, ease of use and consumer } \\
\text { awareness has positive impact on the intention to adopt } \\
\text { internet banking while perceived risk has negative impact on } \\
\text { it. }\end{array}$ \\
\hline 8. & $\begin{array}{l}\text { Majali et al. } \\
\text { (2011) }\end{array}$ & $\begin{array}{l}\text { Jordan, } \\
700 \text { Respondents }\end{array}$ & $\begin{array}{l}\text { Six variables under study perceived ease of use, perceived } \\
\text { usefulness, compatibility, trial ability, trust, awareness have a } \\
\text { significant impact on the customers' internet banking service } \\
\text { adoption. }\end{array}$ \\
\hline 9. & Srivastava et al. & India, & $\begin{array}{l}\text { The perception of the consumers to use internet banking can } \\
\text { be changed by awareness program, friendly usage, less } \\
\text { charges, proper security, and the best response to the }\end{array}$ \\
\hline
\end{tabular}




\begin{tabular}{|l|l|l|l|}
\hline & $(2007)$ & 665 Bank Customers & services offered. \\
\hline 10. & $\begin{array}{l}\text { Adams et al. } \\
(2009)\end{array}$ & $\begin{array}{l}\text { Ghana, } \\
3 \quad \text { Banks, } \\
\text { Respondents }\end{array}$ & $\begin{array}{l}\text { Customer value perceptions depend on cost benefit analysis, } \\
\text { competition and customers expectations. }\end{array}$ \\
\hline
\end{tabular}

\section{OBJECTIVES OF THE STUDY}

The study has been undertaken by taking into view the following objectives:

- To study the impact of internet banking on the service quality of banks in Punjab.

- To make suggestions for improvement of quality of services of banks working in Punjab.

- To identify degree of importance attached to various dimensions and also with its variables of service quality under study viz. reliability, assurance, responsiveness, empathy, tangibility, security, communication.

\section{HYPOTHESIS DEVELOPMENT}

The following null hypothesis has been made to undertake the research:

- $\mathrm{HO}$ : The internet banking has no significant impact on the service quality of banks in Punjab.

- Ho: There is no significant difference in the customer perception and expectation regarding service quality dimensions under this study.

\section{LIMITATIONS OF THE STUDY}

The present study is based upon the results of survey conducted on only 53 respondents. The results of the study are subject to the limitations of sample size, regional territory, psychological, financial and emotional characteristics of surveyed population. Due to such limitations the study cannot be generalized.

\section{RESEARCH METHODOLOGY}

\section{Data Collection}

This research is based upon the primary as well as secondary study. In order to arrive at the sample size, non probability method has been used. For the primary data collection the structured pre tested questionnaire is used to record the response of various respondents. Data is collected from 50 respondents for the purpose of determining the impact of internet banking on the service quality of banks in Punjab. All items were measured by responses on a Five-Point Likert Scale in agreement/relevance with statements, ranging from $1=$ Strongly agree/ Completely relevant to $5=$ Strongly disagree/Completely irrelevant. The sources used for secondary data collection includes research papers, articles, websites of banks, data published by RBI.

\section{Data Analysis}

The reliability of data has been tested through Cronbach Alpha, It has further been analyzed thought descriptive statstics. The analysis of primary data was carried out using Statistical Package for the Social Sciences (SPSS) 20.

\section{PROFILE OF RESPONDENTS}

Table 1: Age of respondent

\begin{tabular}{|c|c|c|c|c|c|}
\hline & & Frequency & Percent & Valid Percent & Cumulative Percent \\
\hline \multirow{3}{*}{ Valid } & $20-40$ & 48 & 96.0 & 96.0 & 96.0 \\
\hline & $40-60$ & 2 & 4.0 & 4.0 & 100.0 \\
\hline & Total & 50 & 100.0 & 100.0 & \\
\hline
\end{tabular}

Table 2: Sex of respondent

\begin{tabular}{|cl|c|c|c|c|}
\hline & & Frequency & Percent & Valid Percent & Cumulative Percent \\
\hline \multirow{3}{*}{ Valid } & Male & 28 & 56.0 & 56.0 & 56.0 \\
& Female & 22 & 44.0 & 44.0 & 100.0 \\
& Total & 50 & 100.0 & 100.0 & \\
\hline
\end{tabular}


Table 3: Marital Status of Respondent

\begin{tabular}{|cl|c|c|c|c|}
\hline & Frequency & Percent & Valid Percent & $\begin{array}{c}\text { Cumulative } \\
\text { Percent }\end{array}$ \\
\hline \multirow{3}{*}{ Valid } & Single & 32 & 64.0 & 64.0 & 64.0 \\
& Married & 18 & 36.0 & 36.0 & 100.0 \\
& Total & 50 & 100.0 & 100.0 & \\
\hline
\end{tabular}

Table 4: Education of Respondent

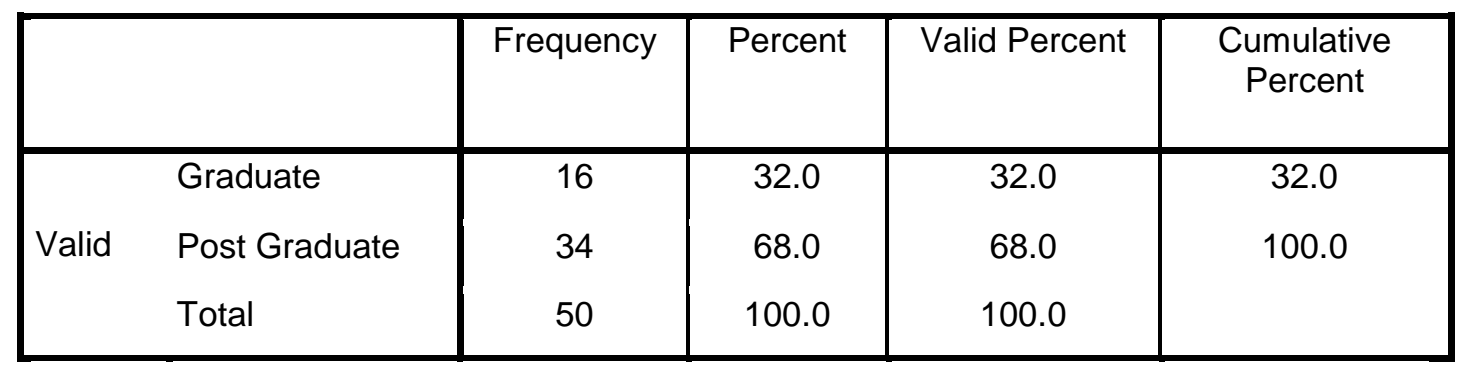

Table 5: Profession of Respondent

\begin{tabular}{|c|c|c|c|c|c|}
\hline & & Frequency & Percent & Valid Percent & $\begin{array}{c}\text { Cumulative } \\
\text { Percent }\end{array}$ \\
\hline & Student & 10 & 20.0 & 20.0 & 20.0 \\
\hline & Housewife & 1 & 2.0 & 2.0 & 22.0 \\
\hline & service & 33 & 66.0 & 66.0 & 88.0 \\
\hline & Business & 1 & 2.0 & 2.0 & 90.0 \\
\hline & Not Employed & 5 & 10.0 & 10.0 & 100.0 \\
\hline & Total & 50 & 100.0 & 100.0 & \\
\hline
\end{tabular}

Table 6: Income of the Respondent

\begin{tabular}{|l|r|r|r|r|}
\hline & Frequency & Percent & Valid Percent & $\begin{array}{c}\text { Cumulative } \\
\text { Percent }\end{array}$ \\
\hline Less Than 5000 & 8 & 16.0 & 16.0 & 16.0 \\
$5,001-10,000$ & 2 & 4.0 & 4.0 & 20.0 \\
Valid & 1 & 2.0 & 2.0 & 22.0 \\
20,001-20,000 & $9001-40,000$ & 18.0 & 18.0 & 40.0 \\
More Than 40,000 & 17 & 34.0 & 34.0 & 74.0 \\
Not Earning & 13 & 26.0 & 26.0 & 100.0 \\
Total & 50 & 100.0 & 100.0 & \\
\hline
\end{tabular}


Table 7: Do You Use Internet Banking

\begin{tabular}{|l|c|c|c|c|}
\hline & Frequency & Percent & Valid Percent & Cumulative Percent \\
\hline Valid Yes & 50 & 100.0 & 100.0 & 100.0 \\
\hline
\end{tabular}

Table 7: Reliability Statistics

\begin{tabular}{|c|c|}
\hline Cronbach's Alpha & N of Items \\
\hline .931 & 37 \\
\hline
\end{tabular}

Table 8: Descriptive Statistics of Dimension Reliability

\begin{tabular}{|c|c|c|c|c|}
\hline & $\mathrm{N}$ & \multicolumn{2}{|c|}{ Mean } & \multirow{2}{*}{$\frac{\text { Std. Deviation }}{\text { Statistic }}$} \\
\hline & Statistic & Statistic & Std. Error & \\
\hline $\begin{array}{l}\text { Services are performed } \\
\text { accurately the first time. }\end{array}$ & 50 & 4.1600 & .09196 & .65027 \\
\hline $\begin{array}{l}\text { Pages of websites do not freeze } \\
\text { when information regarding } \\
\text { transaction is entered. }\end{array}$ & 50 & 4.2000 & .12778 & .90351 \\
\hline $\begin{array}{l}\text { Written guarantee is given that } \\
\text { transactions have taken place. }\end{array}$ & 50 & 4.2200 & .10416 & .73651 \\
\hline $\begin{array}{l}\text { The processing with the help of } \\
\text { internet is error free and efficient. }\end{array}$ & 50 & 4.2600 & .09394 & .66425 \\
\hline $\begin{array}{l}\text { Banks quickly and effectively } \\
\text { correct mistakes entered by the } \\
\text { customers. }\end{array}$ & 50 & 4.3000 & .10400 & .73540 \\
\hline $\begin{array}{l}\text { The speed of log out your } \\
\text { account is fast. }\end{array}$ & 50 & 4.3800 & .09852 & .69664 \\
\hline $\begin{array}{l}\text { Accurate and error free records } \\
\text { are maintained and provided to } \\
\text { the customer. }\end{array}$ & 50 & 4.4000 & .08571 & .60609 \\
\hline $\begin{array}{l}\text { Services are performed at } \\
\text { promised time. }\end{array}$ & 50 & 4.4000 & .08571 & .60609 \\
\hline $\begin{array}{l}\text { It is easy to find all the important } \\
\text { information from the bank's } \\
\text { website. }\end{array}$ & 50 & 4.4600 & .08187 & .57888 \\
\hline $\begin{array}{l}\text { Exact services are delivered to } \\
\text { the customers as promised by } \\
\text { the bank. }\end{array}$ & 50 & 4.5200 & .07688 & .54361 \\
\hline Valid N & 50 & & & \\
\hline
\end{tabular}

The table 8 shows that reliability is an effective dimension to study the impact of internet banking on the service quality of banks in Punjab. Ten variables have been included in this dimension to study the response of various users of internet banking. Among these variables the last variable has maximum mean of 4.520 which shows that users are getting the exact services as promised by their banks to them. In the table we have shown the variables in the ascending order that is the variable which counts more to study this variable is at last and the variable which has minimum impact in this study is at top. And the variable having least response is related with the fact that banks are not very much able to perform services accurately in the very first attempt of the user. But still the variables under study of this dimension have given positive results and proved that reliability put significant impact on the service quality of banks offering internet banking to their customers. 
Table 9: Descriptive Statistics of Dimension Assurance

\begin{tabular}{|c|c|c|c|c|}
\hline & \multirow{2}{*}{$\frac{\mathrm{N}}{\text { Statistic }}$} & \multicolumn{2}{|c|}{ Mean } & \multirow{2}{*}{$\begin{array}{c}\text { Std. Deviation } \\
\text { Statistic }\end{array}$} \\
\hline & & Statistic & Std. Error & \\
\hline $\begin{array}{l}\text { Employees are very polite } \\
\text { towards the customers. }\end{array}$ & 50 & 3.9600 & .12108 & .85619 \\
\hline $\begin{array}{l}\text { Proper feedback is provided to } \\
\text { the customers. }\end{array}$ & 50 & 4.1400 & .09902 & .70015 \\
\hline $\begin{array}{l}\text { Employees are instilling } \\
\text { confidence among the } \\
\text { customers. }\end{array}$ & 50 & 4.1800 & .11317 & .80026 \\
\hline $\begin{array}{l}\text { Employees are competent to } \\
\text { answer the questions of } \\
\text { customers. }\end{array}$ & 50 & 4.2200 & .10016 & .70826 \\
\hline $\begin{array}{l}\text { Making customers feel safe in } \\
\text { their transactions. }\end{array}$ & 50 & 4.4200 & .08127 & .57463 \\
\hline Valid N & 50 & & & \\
\hline
\end{tabular}

The table 9 depicts that users agreed that assurance is a factor which impacts the service quality of the banks. The variable with the highest mean 4.420 in this dimension provides that each and every possible attempt is undertaken by the banks which will make their customers feel safe in their transactions on internet. Five variables are covered in this dimension to study the impact. This is the dimension which is having the least mean variable as compared to other dimensions. The variable at the top in this table has mean value of 3.96 which provides that minimum respondents are agreeing with the research question that employees of the banks are polite towards them. The respondents of the study proved that employees are competent to answer the questions of customers, are instilling confidence among them and also provide feedback to them when required.

Table 10: Descriptive Statistics of Dimension Responsiveness

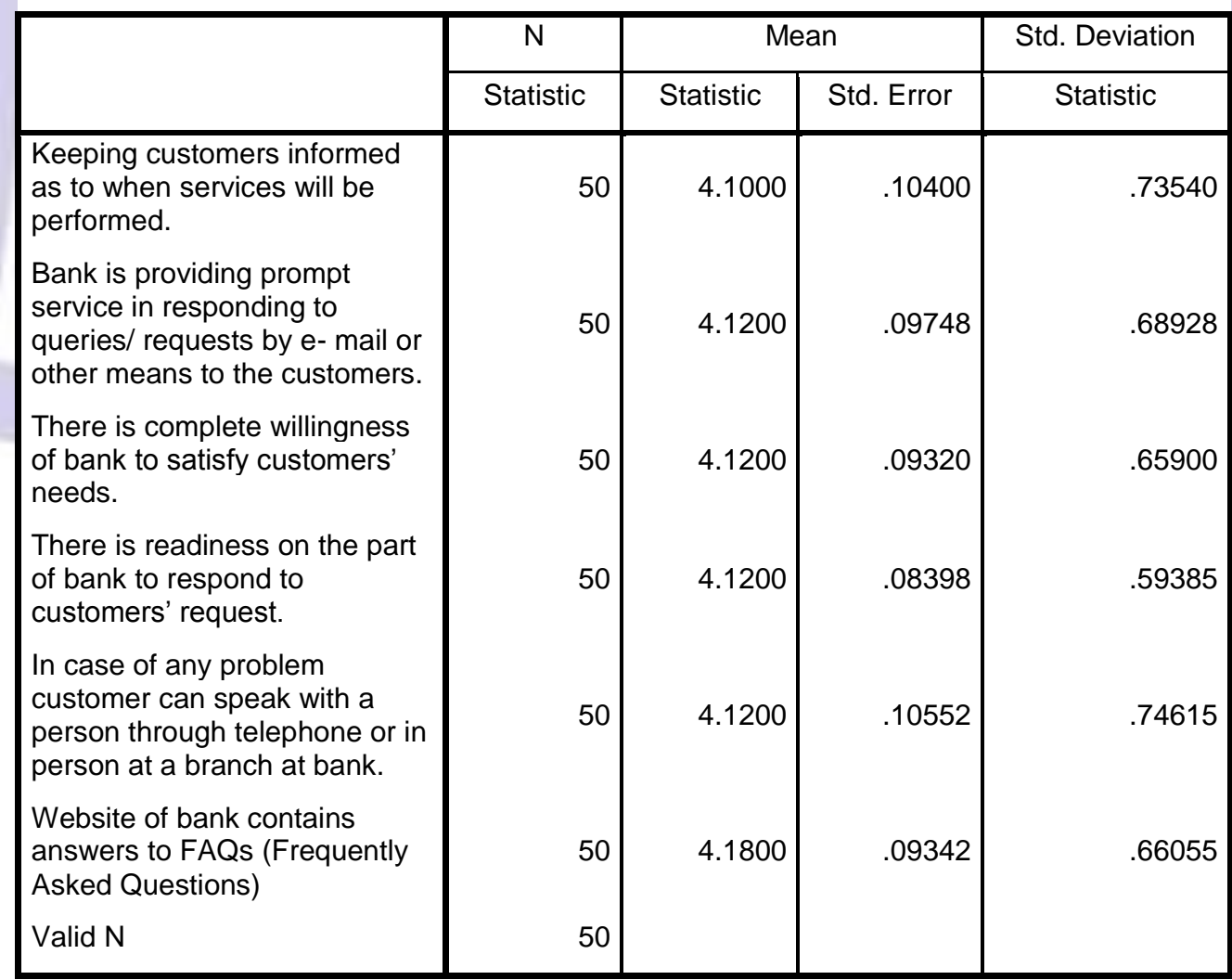


Table 10 provides that six variables are included in the dimension of Responsiveness to study the behavior of internet banking users. The variable with the highest mean 4.18 of this dimension present that maximum respondents are agreed with this variable of dimension that websites of their respective banks contains answers to FAQs (Frequently Asked Questions). The least mean value 4.10 of this dimension discloses the fact that the respondents has given their positive comments for the research question that they are keeping informed by the banks as to when services will be performed. The other thing which we want to highlight in this study is that this is the dimension on which least respondents have agreed on the maximum mean value variable. It means that the highest mean value variable of this dimension has the lowest mean value as compared to other highest mean values of other six dimensions.

Table 11: Descriptive Statistics of Dimension Empathy

\begin{tabular}{|c|c|c|c|c|}
\hline & $\mathrm{N}$ & $\mathrm{M \epsilon}$ & & Std. Deviation \\
\hline & Statistic & Statistic & Std. Error & Statistic \\
\hline $\begin{array}{l}\text { Individual attention is given to the } \\
\text { customer. }\end{array}$ & 50 & 4.0800 & .09831 & .69517 \\
\hline $\begin{array}{l}\text { Employees have the customers' } \\
\text { best interest in their mind. }\end{array}$ & 50 & 4.1400 & .10306 & .72871 \\
\hline $\begin{array}{l}\text { Employees understand the } \\
\text { problems of the customers. }\end{array}$ & 50 & 4.1800 & .11317 & .80026 \\
\hline $\begin{array}{l}\text { Employees are dealing with } \\
\text { customers in a concerning } \\
\text { manner. }\end{array}$ & 50 & 4.2400 & .07856 & .55549 \\
\hline Valid N & 50 & & & \\
\hline
\end{tabular}

Table 11 deals with the dimension Empathy with the four variables. The variable named employees are dealing with customers in a concerning manner has the highest mean value 4.24 and the variable with the research question that individual attention is given to the customers has the least mean value of 4.08 in this dimension. The other facts which are proved in this research of this dimension are that employees of the banks have the customers' best interest in their mind and also they understand the problems of the customers.

Table 12: Descriptive Statistics of Dimension Tangibility

\begin{tabular}{|c|c|c|c|c|}
\hline & \multirow{2}{*}{$\frac{\mathrm{N}}{\text { Statistic }}$} & \multicolumn{2}{|c|}{ Mean } & \multirow{2}{*}{$\frac{\text { Std. Deviation }}{\text { Statistic }}$} \\
\hline & & Statistic & Std. Error & \\
\hline $\begin{array}{l}\text { There is visually appealing } \\
\text { material associated with the } \\
\text { service. }\end{array}$ & 50 & 4.3000 & .09583 & .67763 \\
\hline $\begin{array}{l}\text { Bank has visually appealing } \\
\text { facilities. }\end{array}$ & 50 & 4.4000 & .08571 & .60609 \\
\hline $\begin{array}{l}\text { Employees have a neat, } \\
\text { professional appearance. }\end{array}$ & 50 & 4.4200 & .09515 & .67279 \\
\hline $\begin{array}{l}\text { Bank has modern looking } \\
\text { equipments. }\end{array}$ & 50 & 4.4400 & .09107 & .64397 \\
\hline Business hours are convenient. & 50 & 4.4400 & .09545 & .67491 \\
\hline Bank location is convenient. & 50 & 4.4800 & .08202 & .57994 \\
\hline Valid N & 50 & & & \\
\hline
\end{tabular}

The above table shows that tangibility also affecting the service quality of banks. The maximum respondents agree that bank location and banking hours are important factors affecting service quality of banks. Internet banking users also proves that banks provide visually appealing material and facilities associated with the service. The neat and clean 
appearance of employees, modern looking equipments also have a positive impact on the service quality of banks offering internet banking to their customers.

Table 13: Descriptive Statistics of Dimension Security

\begin{tabular}{|c|c|c|c|c|}
\hline & $\mathrm{N}$ & \multicolumn{2}{|c|}{ Mean } & \multirow{2}{*}{$\frac{\text { Std. Deviation }}{\text { Statistic }}$} \\
\hline & Statistic & Statistic & Std. Error & \\
\hline $\begin{array}{l}\text { You are confident with } \\
\text { management of customer's } \\
\text { personal information held in the } \\
\text { bank. }\end{array}$ & 50 & 4.1400 & .10306 & .72871 \\
\hline $\begin{array}{l}\text { All files of customers and } \\
\text { banking records related to } \\
\text { transactions are safely kept. }\end{array}$ & 50 & 4.1800 & .10951 & .77433 \\
\hline $\begin{array}{l}\text { Clients' are confident that } \\
\text { services provided were done in } \\
\text { a secured manner. }\end{array}$ & 50 & 4.2800 & .10317 & .72955 \\
\hline Valid N & 50 & & & \\
\hline
\end{tabular}

Table 13 depicts that security puts positive impact on the service quality of banks providing internet banking services. Last variable of the table with highest mean value 4.280 shows that customers are confident that the services which are provided to them were done in a secured manner. Respondents also prove that their all files and banking records related to transactions are safely kept by the banks. Customers are confident regarding the management of their personal information held in the bank.

Table 14: Descriptive Statistics of Dimension Communication

\begin{tabular}{|c|c|c|c|c|}
\hline & \multirow{2}{*}{$\frac{\mathrm{N}}{\text { Statistic }}$} & \multicolumn{2}{|c|}{ Mean } & \multirow{2}{*}{$\frac{\text { Std. Deviation }}{\text { Statistic }}$} \\
\hline & & Statistic & Std. Error & \\
\hline $\begin{array}{l}\text { Bank provides multiple } \\
\text { languages offering online. }\end{array}$ & 50 & 4.3800 & .11025 & .77959 \\
\hline $\begin{array}{l}\text { Bank ensures that customers } \\
\text { informed in a language they can } \\
\text { understand online. }\end{array}$ & 50 & 4.4400 & .10365 & .73290 \\
\hline $\begin{array}{l}\text { Internet makes communication } \\
\text { easier and work efficient. }\end{array}$ & 50 & 4.7200 & .06414 & .45356 \\
\hline Valid N & 50 & & & \\
\hline
\end{tabular}

Table 14 proves that the communication dimension is the most effective dimension of the study and proves that it is the maximum affecting dimension to the service quality of banks with internet banking service. This dimension has the highest mean value variable as compared to other dimensions with 4.720 which provides that internet makes communication easier and effective. The lowest mean value of this dimension is 4.38 which are highest in the least mean value variables of all dimensions. This dimension proves that communication has a positive impact on the service quality of banks offering internet banking to their customers.

\section{RESULTS AND DISCUSSIONS}

1. Maximum users of internet banking are covered under the age group of 20-40.

2. The results prove that the income of the respondents is independents to the usage of internet banking. 
2. The profession of maximum users of internet banking in this study is in service and after this they are student.

3. Education has a positive role in the adoption of internet banking of the customers as the maximum users are either graduate or post graduate.

4. $36 \%$ respondents are strongly agreeing and $56 \%$ are agreeing that the processing with the help of internet is error free and efficient.

5. Maximum respondent i.e. $26 \%$ are strongly agree and $68 \%$ are agreeing with the statement that services are performed accurately the first time with the help of internet banking by the customers.

6. From the total $38 \%$ are strongly agreeing and $48 \%$ agreeing with the fact that written guarantee is given by the banks to them that transactions have taken place.

7. Accurate and error free records are maintained and provided to the customer and services are performed at promised time by the bank. This fact is supported by $94 \%$ respondents who are strongly agreeing and only agreeing on this.

8. $98 \%$ respondents from the total are agreed on the fact exact services are delivered to the customers as promised by the bank.

9. From the total $84 \%$ respondents are supporting the fact that pages of websites do not freeze when information regarding transaction is entered. But $8 \%$ respondents are such who have neutral response on this and rest of the $8 \%$ disagree with this fact.

10. $92 \%$ of the total respondents are agreeing with the fact that banks quickly and effectively correct mistakes entered by the customers.

11. Maximum respondents are supporting the fact that it is easy to find all the important information from the bank's website.

12. $48 \%$ respondents are strongly agreeing and $44 \%$ are agreeing that the speed of log out from their account is fast.

13. $96 \%$ respondents are agreeing that their respective banks making customers feel safe in their internet banking transactions.

14. Employees are competent to answer the questions of customers. This fact is also supported by $86 \%$ respondents. But $10 \%$ respondents have neutral response on this.

15. From the total respondents $36 \%$ are strongly agreeing and $52 \%$ are agreeing that employees are instilling confidence among the customers using internet banking. But $6 \%$ respondents are neutral and rest of the $6 \%$ is disagreeing with this fact.

16. $28 \%$ respondents from the total are strongly agreeing and $46 \%$ only agreeing that employees are very polite towards the customers. $20 \%$ have neutral response and $6 \%$ are disagreeing with this fact.

17. Proper feedback is provided to the customers using internet banking and bank is providing prompt service in responding to queries/ requests by e- mail or other means to the customers is proved by $82 \%$ respondents and $18 \%$ have neutral response on this fact.

18. $62 \%$ respondents are agreeing and $26 \%$ are strongly agreeing that there is complete willingness of bank to satisfy customers' needs. Only $10 \%$ have neutral response and $2 \%$ are disagreeing on this statement.

19. From the total $88 \%$ respondents proves that there is readiness on the part of bank to respond to customers' request and rest of the $12 \%$ have neutral response on this.

20. From the total $86 \%$ respondents proves that website of bank contains answers to FAQs (Frequently Asked Questions) and rest of the $14 \%$ have neutral response on this fact.

21. This research proves that in case of any problem customer can speak with a person through telephone or in person at a branch at bank. The response of $82 \%$ respondents is in favor of this statement but $16 \%$ of the respondents have neutral response for this research question.

22. Maximum respondents in study agree with the research question that they are informed by the bank as to when services will get performed. Only $10 \%$ are neutral and rest $4 \%$ are disagree with this research question.

23. $76 \%$ respondents are in favor that individual attention is given to the customer by the banks but $14 \%$ have neutral answer to the same.

24. Only $30 \%$ respondents are strongly agree and $64 \%$ are agreeing that employees are dealing with customers in a concerning manner.

25. The research question titled employees have the customers' best interest in their mind is proved right by $88 \%$ of the total respondents.

26. $78 \%$ of the total respondents are agreeing that employees understand the problems of the customers. But $8 \%$ of them have neutral response and $4 \%$ are disagreeing. 
27. More than $80 \%$ respondents from the study are in the favor that bank has modern looking equipments and visually appealing facilities.

28. $90 \%$ respondents are in the favor that employees of the banks have a neat, professional appearance.

29. Maximum respondents are satisfied with the business hours i.e. 24/7 in case of internet banking and bank location and these respondents are also agreeing that there is visually appealing material associated with the service.

30. As far as the security factor is concerned $44 \%$ respondents are strongly agree and $40 \%$ are agreeing that they are confident that services provided were done in a secured manner. But $16 \%$ respondents are neutral to the same.

$31.80 \%$ of respondents are secured and confident with management of customer's personal information held in the bank. $20 \%$ of the respondents are neither satisfied nor dissatisfied.

32. From the total $88 \%$ of the respondents are satisfied with the fact that all files of customers regarding banking records and transactions are safely kept. 165 are neutral and $2 \%$ are dissatisfied to the same.

33. Maximum of the respondents is agreeing that bank provides multiple languages offering online and bank ensures that customers informed in a language they can understand online.

$34.72 \%$ respondents are strongly agreed and $28 \%$ are agreeing that internet banking makes communication easier and work efficient.

\section{CONCLUDING REMARKS}

The research proves that all the dimensions which are included in the study have a positive impact on the service quality of banks providing internet banking services to their customers in Punjab. The communication has a very strong role to improve the service quality of the banks providing internet banking services. The order of the importance of dimensions provides communication at the top following reliability, tangibility, assurance, security, empathy and responsiveness. The study concludes that security is not the dimension which negatively impacts the service quality of banks as proved in earlier researches. As per this research paper tangibility and assurance are the factors which have least positive impact on the service quality of banks providing internet banking services to their customers. The gap prevails in the perceived quality and expected quality of dimensions tangibility and assurance can be minimized to the extent if banks ensure their customers that employees of the banks will always become polite to them and banks need to implement it from grass root level in their organisation structure. The banks also need to provide material on their websites in the form of guidance tips which will help the users to enjoy internet banking services without any difficulty.

\section{REFERENCES:}

1. Adams,N. A. and Lamptey , A. D. ,(2009), "Customer Perceived Value in Internet banking in Ghana," Master Thesis, Continuation Courses, Luela University of Technology, Sweden.

2. Adapta, S., (2008), "Adoption of Internet Shopping: Cultural Considerations in India and Australia", Journal of Internet Banking and Commerce, 13(2), pp. 7-13.

3. Altıntaş, M. K., and Gürsakal, N., (2007), "Phishing Attacks and Perceptions of Service Quality: A Content Analysis of Internet Banking in Turkey", Journal of Internet Banking and Commerce, 12(2), pp. 6-10.

4. De Jager, H. J., Nieuwenhuis, F. J. (2005). "Linkages between Total Quality Management and the Outcomes based Approach in an Education Environment", Quality in Higher Education, 11 (3): 252-254.

5. Dixit, N., and Datta, S. K., (2010), "Acceptance of E-banking among Adult Customers: An Empirical Investigation in India", Journal of Internet Banking and Commerce, 15(2), pp. 8-14.

6. Hassan, M.T. (2012). "Customer Service Quality Perception of Internet Banking", International Journal of Learning and Development, 2(2): 87-91.

7. Majali M.A. and Kamariah, S.K., (2011), "Modeling the Antecedents of Internet Banking Service Adoption (IBSA) in Jordan: A Structural Equation Modeling (SEM) Approach", Journal of Internet Banking and Commerce, 16(1), pp. 1-13.

8. Parasuraman, A., Zeithaml, V.A. and et al., (1988), "SERVQUAL: A Multiple-Item Scale for Measuring Consumer Perceptions of Service Quality", Journal of Retailing, 64(1): 12-40.

9. Raman, M.and Stephenaus, R. et al., (2008), "Information Technology in Malaysia: E-service quality and Uptake of Internet banking", Journal of Internet Banking and Commerce,13(2), pp. 6-14.

10. Rullis, H. and Sloka, B., (2011), "Internet Banking Quality: Marketing Possibilities and Customers' Loyalty", Journal of Management Theory and Studies for Rural Business and Infrastructure Development, 2(26), pp. 195199.

11. Safeena, R., Abdullah, (2010), "Customer Perspectives on E-business Value: Case Study on Internet Banking", Journal of Internet Banking and Commerce, 15(1), pp. 7-11.

12. Shrivastava, R.K., (2007), "Customer's Perception on Usage of Internet Banking", Journal of Innovative Marketing, 3(4), pp. 67-73.

13. Vasagadekar, P., (2012), "A Study on the Psychology of An Indian Customer Towards E-Banking with Reference to Pune Region",International Journal of Scientific \& Engineering Research, 3(11), pp.184-197. 